\title{
Exploring the potential for "urban air quality transition management" in the EU - lessons from the City of Aachen (Germany)
}

\author{
Paul Szabo-Müller(i)
}

\author{
Correspondence: Paul.Szabo. \\ Mueller@rwth-aachen.de \\ RWTH Aachen University, Economic \\ Geography, Templergraben 55, \\ 52056 Aachen, Germany
}

\begin{abstract}
Air pollution is one of the most important global sustainability and health challenges. In response to this, the European Union (EU) initiated with its Directive 2008/50/EC a new era of (urban) air quality management (UAQM) and introduced air quality plans and short term action plans as major formal planning instruments. However, these efforts still fail to achieve their target. Independently, sustainability transitions research emerged as a major science field, suggesting urban transition management (UTM) as an effective governance and planning approach for steering transformative urban change. Hence, the overall query this paper puts forward is, whether UAQM could be enhanced by UTM? This leads to an empirical and a conceptual question: 1) How transformative is current UAQM, i.e. how does it contribute to a transition process? 2) How could UAQM and UTM be combined to create an 'urban air quality transition management'? Drawing on a conceptual discussion of both frameworks, an explorative case study of UAQM in the EU and the City of Aachen (Germany) reveals that UAQM and UTM seem to have many similarities at a superficial level, but differ significantly in detail. They are mostly complementary because each approach has its own strengths and weaknesses, so that neither of them could achieve the targeted transition alone. Future research should therefore focus on comparative transformative research in 'urban air quality transition management labs' to develop integrated approaches. Policy should both legally facilitate such experiments and deliver sufficient funding for enhanced UAQM in general.
\end{abstract}

Keywords: Air quality management, Air quality plan, Air pollution, Transition management, Sustainability transition, EU, Air quality directive, Health, Urban

\section{Science highlights}

- Air pollution is one of the most important global sustainability and health challenges

- Urban Air Quality Management and Urban Transition Management are complementary, but practically separated approaches

- An explorative case study in the City of Aachen (Germany) is used to juxtapose both approaches

- Comparative transformative research in "urban air quality transition management" labs could help to integrate both approaches

(c) The Author(s). 2019 Open Access This article is distributed under the terms of the Creative Commons Attribution 4.0 International License (http://creativecommons.org/licenses/by/4.0/), which permits unrestricted use, distribution, and reproduction in any medium, provided you give appropriate credit to the original author(s) and the source, provide a link to the Creative Commons license, and indicate if changes were made. The Creative Commons Public Domain Dedication waiver (http://creativecommons.org/ publicdomain/zero/1.0/) applies to the data made available in this article, unless otherwise stated. 


\section{Policy and practice recommendations}

- Legally facilitate experiments with "urban air quality transition management"

- Provide reliable financial resources (e.g. transition funds) and political support from all levels

- Pursue a long-term transition strategy that goes beyond limit value compliance

- Use air pollution for piloting urban transition management (e.g. transition labs, citizen sensing)

\section{Introduction: air pollution and urban air quality management (UAQM)}

Air pollution is one of the most important global sustainability and health challenges of our time and hence a major field of transformative urban change (WBGU 2016). It stems from multiple anthropogenic sources such as agriculture, energy, industry or transport and causes harmful effects on the climate, eco-systems, built environment, cultural heritage, economy and particularly human health (cf. EEA 2017). Both the causes and impacts of air pollution are strongly related to the global megatrend of urbanization, since urban areas play a crucial role as sources as well as places of highest pollutant concentrations and their adverse effects. According to the World Health Organization (WHO 2018) in 2016 91\% of the world population lived in areas where the WHO Air Quality Guidelines were exceeded. This is attributed with approximately 4.2 Million premature deaths, of which $91 \%$ occur in low- to middle-income countries (these countries also face big problems with indoor air pollution, leading to approx. 3.8 Million premature deaths). Unsurprisingly, almost all of the Sustainable Development Goals (SDGs) of the UN Agenda 2030, which is the global roadmap for sustainable development until 2030, relate directly or indirectly to air pollution (EEA 2017). For instance, three SDG progress-indicators explicitly focus on air pollution (i.e. No. 3.9.1, 7.1.2, 11.6.2; WHO 2016). Air pollution is also a major sustainability challenge in Europe and the European Union (EU). Evidently, air pollutants such as Particulate Matter (PM), Nitrogen Dioxide $\left(\mathrm{NO}_{2}\right)$ as well as ground-level Ozone $\left(\mathrm{O}_{3}\right)$ do serious harm to human health and cause, for example, lung cancer, respiratory or cardiovascular diseases. According to the European Environment Agency (EEA 2017) 428,000 premature deaths in Europe (approx. 400,000 in the EU-28) are attributable to long-term exposure with $\mathrm{PM}_{2,5}, 78,000(75,000)$ to $\mathrm{NO}_{2}, 14,400(13,600)$ to $\mathrm{O}_{3}$.

In response to these challenges, air quality policy frameworks and urban air quality management (UAQM) approaches have been designed around the world, which typically include eight interrelated elements (Gulia et al. 2015): 1) objectives/standards, 2) monitoring, 3) source apportionment, 4) emission inventory, 5) modelling, 6) exposure and health assessment, 7) strategies, 8) public participation. For instance, the EU air quality policy framework is the result of more than 40 years of joint environmental policy in the EU and was intensively reshaped in the course of the 6th EU Environment Action Programme (EC 2005, 2018). Particularly with its "Ambient Air Quality Directive" 2008/50/EC (AAQD) the EU initiated a new era of (U)AQM and introduced air quality plans and short term action plans as major formal planning instruments (i.e. air quality 'planning') to fight against air pollution in Europe (EU 2015).

The directive provides the major legal basis and regulates the whole (U)AQM process in Europe, including obligations for Member States to implement air quality plans in 
case of limit value exceedances, for instance those for $\mathrm{PM}_{10}$ and $\mathrm{NO}_{2}$. Exceedances mostly occur within urban areas and are caused by urban transport, hence most air quality plans are implemented in urban areas and focus on urban transport (EEA 2018a). In a follow-up of an earlier study (EEA 2018b, 2019) the ten participating cities reported that within 5 years they have improved their UAQM in terms of assessment tools and methods and gained a better understanding of sources of local air pollution. However communication, engaging with citizens and gaining acceptance for new air quality measures in policy and society is still challenging, particularly when EU air quality standards are met. A further challenge is achieving policy coherence across administrative and governance levels. Results from other studies point in a similar direction. For example Barnes et al. (2018) identified a "policy disconnect" in the UK and argue further that a "failure of EU and national air quality policies has effectively undermined local authority action to improve local air quality" (e.g. Euro vehicle standards, lack of accountability at the local level, inconsistent EU and national requirements). In the project PM-Lab similar observations have been made in the three-country triangle of Belgium, Germany and the Netherlands, the so called Euregio-Meuse Rhine (Severijnen 2014). In addition it was found that, despite the common umbrella of the AAQD and some similar looking measures (e.g. in the transport sector), the way in which UAQM is carried out - and with what intensity - differs from city to city (e.g. Aachen (Germany), Genk and Liege (both Belgium), Heerlen and Maastricht (Netherlands)). This depends not least on the respective national-regional contexts including for instance air quality related determinants such as different emission sources, concentration situations, pollutants as well as more general factors like the socio-economic situation and divisions of competences across administrative levels.

Despite some progress, the EU Air Quality Policy still fails to meet its targets and limit values are still exceeded all over Europe (EEA 2015, 2017). This is in spite of a further revision that resulted in the adoption of a new Clean Air Policy Package in 2013 that includes a set of revised and new directives (EC 2013). There still seems to be a challenging gap between, on the one hand, efficiently organised UAQM in terms of standard definition, emission inventories, monitoring, assessments and reporting etc., which is, on the other hand, not effective in terms of limit value compliance.

Apart from that, more recently urban transition management (UTM) (Frantzeskaki et al. 2018a; Loorbach et al. 2016; Nevens et al. 2013; Roorda et al. 2014) and urban transition planning (Wolfram 2018) are emerging approaches for governing sustainable urban change that may have something to offer for UAQM, but are not linked to it yet. Both are based on the idea of Transition Management, which aims to initiate and guide an open governance process targeting systemic change for sustainability (Loorbach and Rotmans 2010).

Given the situation that air quality policy still fails to achieve air quality levels that are sufficient to protect public health, the overall research question of this paper is, whether UAQM could be enhanced by UTM in order to meet air quality targets in future. Answering this requires elaboration on two subsequent questions, one empirical and the other conceptual: 1) How transformative is current UAQM, i.e. how does it contribute to a transition process? 2) How could UAQM and UTM be combined in terms of an 'urban air quality transition management'?

The remainder of this paper is structured as follows: The next Conceptual approach section introduces the conceptual background of UTM as a means of urban transition 
planning and develops an approach for a juxtaposition with UAQM. Methods section presents the reasons and methods used for applying the approach in the following Case study: UAQM in the City of Aachen (Germany) section. Discussion: juxtaposing UAQM and UTM section discusses the findings in relation to the research questions, and Conclusions section draws final conclusions and recommendations for policy as well as future research.

\section{Conceptual approach}

\section{Sustainability transitions}

In parallel to the new era of air quality policy in the EU, sustainability transitions became a major field of research, focusing on long-term fundamental transformation processes to more sustainable socio-technical systems (Markard et al. 2012). Examples include the shift from fossil fuel based to renewable energy, from internal combustion engine based (e.g. car) to low carbon transport as well as from industrialised agriculture to organic farming.

According to the Multi-Level Perspective (MLP), socio-technical systems are constituted by three analytical levels, namely the regime, niche and landscape. These can be described as follows (Geels 2011): The regime is the level where dominant and stable "established practices and associated rules" prevail (e.g. related to energy provision from large combustion plants, car based transport systems etc.), which may prevent sustainable structural change due to several lock-ins. Contrary to this, the niche includes "practices or technologies that deviate substantially from the existing regime" (e.g. radical innovations like renewable energy or alternative propulsion technologies). The landscape is defined as the "external environment that influences niche(s) and regime"; external because it cannot be influenced by them in the short term. Alongside the analytical focus of the MLP, questions about suitable governance approaches were of particular interest right from the beginning of sustainability transition research.

But surprisingly, an explicit connection between sustainability transition research and air pollution and consequently UAQM is still lacking today - despite the fact that sociotechnical systems can be associated with the respective sources of air pollution and that, for example, synergies with the promotion of urban low-carbon transitions or transitions to sustainable urban mobility are obvious. Furthermore, environmental legislation and policy can be an important influencing factor of transitions (cf. de Haan and Rotmans 2011), yet the AAQD has not been investigated by transition studies whereas in practice there is to date no (formal) UAQM process that explicitly uses an UTM approach. However, there are some transition-like approaches for UAQM such as citizen sensing and related initiatives (see Discussion: juxtaposing UAQM and UTM section). All in all, the growing attention to transition geographies, and consequently to UTM and transition planning offer promising potential for a connection with UAQM. Firstly, while there was rather low engagement for a long time, the geography of sustainability transitions has received increasing attention in recent years: "Questions concerning where sustainability transitions take place and why have thus remained largely off the radar in this otherwise burgeoning field of studies" (Coenen and Truffer 2012). Contemporary contributions consider more intensively the related building blocks of transition geography, i.e. socio-spatial embedding, multi-scalarity and issues of power (Truffer et al. 2015). Secondly, among these, particularly urban transition management (UTM) seems to have potential for UAQM, because it becomes more and more a transition governance tool for urban areas 
(Frantzeskaki et al. 2018a; Loorbach et al. 2016; Nevens et al. 2013; Roorda et al. 2014) and, thirdly, it is closely related to urban planning (Wolfram 2018).

\section{Urban transition management (UTM)}

In recent years, UTM and urban transition labs have become a synonym for the governance of urban sustainability transitions (Frantzeskaki et al. 2018b; Loorbach et al. 2016; Marvin et al. 2018a; Nevens et al. 2013; Roorda et al. 2014). Conceptually, Transition Management consists of four elements: i) the underlying principles of transition governance, ii) their translation into a transition management framework (i.e. the Transition Management Cycle) as well as iii) instruments and iv) process methodologies for operationalization (Wittmayer and Loorbach 2016). Transition Management is the result of ongoing co-evolutionary conceptual and practical work around different empirical cases with great emphasis on being a concept that can be applied in policy (Loorbach and Rotmans 2010). Theoretically, Transition Management is based on complex systems theory as well as on new forms of governance. Practically, " $t]$ he essence of transition management is that it focuses on the content as well as the process by organizing an interactive and selective participatory stakeholder searching process aimed at learning and experimenting" (Loorbach and Rotmans 2010). Furthermore, the underlying theoretical approaches are synthesised in the so called Transition Management Cycle, which structures the practical activities of the TM process into four fields of activity and respective instruments: i) problem structuring, ii) establishment of a transition arena, iii) developing a transition agenda, sustainability visions and pathways, iii) initiating and executing transition experiments, iv) evaluating, monitoring and learning (ibid).

The first application of Transition Management took place in the course of the regional cooperation process in the former mining region Parkstad Limburg (Netherlands). Other early applications include initiatives and programmes focusing on new sustainable functions of roofs, new approaches to long-term care in the healthcare sector in the Netherlands, as well as the transition of waste management in the Flemish Region (Belgium) to a more resource oriented policy. On a larger scale, transition management was for instance applied in the course of the 4th Dutch National Environmental Policy Plan (Loorbach and Rotmans 2010).

Later, the Transition Management approach was also adapted and transferred to the urban context, often applied in so called urban transition labs, which build on the idea of urban living labs (Loorbach et al. 2016; Marvin et al. 2018b; Nevens et al. 2013; Roorda et al. 2014). Urban Transition Labs are defined as "[...] settings in which real life trajectories of sustainable development in cities are deployed and at the same time carefully observed; in a co-creative collaboration between actors and researchers (transdisciplinary research)" (Nevens et al. 2013). Hence, they reflect all constituting elements and make use of the above described Transition Management instruments, usually coordinated by a transition team. Fourth, finally and more generally, Transition Management and its instruments were made operable for urban contexts through the design of different process methodologies (Roorda et al. 2014; Wittmayer and Loorbach 2016). Examples of UTM applications range from rather 'classic' transition topics to even broader socio-economic projects (see contributions in Loorbach et al. 2016). Examples for the former are the "climate arena" in Ghent (Belgium) that works towards climate neutrality, the elaboration of a local climate plan in Montreuil (France) as well as activities in Aberdeen (UK) to address social and financial 
vulnerabilities arising in the transition away from an oil-dominated economy. Examples for the latter include the promotion of environmental business in the industrially polluted city of Kitakyushu (Japan) or the establishment of a "Welfare Mall" in Higashiomi (Japan), which integrates local production of food, energy, and elderly care.

The focus on the urban scale is also one of the responses to early criticism of transition management, blaming this approach for a lack of consideration of power, politics and agency, an unreflected notion of sustainability, as well as problems arising from coproduction of the concept by researchers, policy-makers and other practitioners (Avelino and Grin 2017; Wittmayer and Loorbach 2016). The urban context plays a crucial role in transitions and, alongside other factors, determines the transformative and related organisational capacity of cities (cf. Hölscher 2018). For Instance, the German Advisory Council on Global Change (WBGU 2016) defined context specificities ("Eigenart") as a core dimension of its normative compass for urban sustainability transformations along with sustaining the natural life-support systems and inclusion. However, in both the analysis and practice of urban sustainability transition governance the question remains of how exactly the politicalinstitutional contexts of cities and municipalities determine their roles and capabilities for achieving fundamental sustainable change. In general, this refers to the Multi-Level Governance settings (Ehnert et al. 2018) in which cities are embedded, and in particular to urban living labs or urban transition labs, respectively (Kronsell and Mukhtar-Landgren 2018). Hence, a major question is whether transition labs - and UTM in general - are suitable governance settings, if legally established and formally institutionalised domains such as UAQM are addressed. Perhaps a transition planning perspective is even more sensitive to this issue.

\section{Transition planning}

Planning is one of several perspectives on the convergence of sustainability transition and spatial research (Egermann and Hutter 2014). However, a planning perspective raises also further questions regarding the practical realisation of sustainability transitions in complex urban contexts. For instance, Wolfram (2018) juxtaposed the transition management approach with basic planning rationalities (i.e. Rationalism, Incrementalism, Participation and Advocacy, Collaborative Planning, Strategic Planning, Multi-level- and Metropolitan Governance) and instruments of urban planning (i.e. Spatial Plans, Sectoral and Thematic Plans, Environmental Assessments, Strategic Plans). By using governance modes, planning instruments and applied techniques as analysis categories, he compared the underlying key features for both approaches (see Fig. 1) and thus identified commonalities and differences, as well as respective strengths and weaknesses. In order to deal with the heterogeneity of fully institutionalised urban planning approaches and the usually experimental transition management approach, he proposed "establishing a dialectic relation of coordinated independence between transition management and urban planning" (Wolfram 2018). This also aligns with other contributions on the topic (Nevens et al. 2013; Wittmayer and Loorbach 2016). In the following, these findings are taken as a starting point to go one step further by comparing and juxtaposing UTM with UAQM - a fully institutionalised field of urban environmental planning.

\section{Approach for juxtaposing UAQM and UTM}

UAQM and UTM can be regarded as two process frameworks for sustainable urban change. However due to their different designs, criteria for comparison are required (see 


\begin{tabular}{|c|c|c|c|c|c|}
\hline \multicolumn{6}{|c|}{ Process Frameworks } \\
\hline & \multicolumn{3}{|c|}{ Urban Transition Management (UTM) } \\
\hline \multicolumn{3}{|c|}{$\begin{array}{l}\text { Urban Air Quality Management (UAQM } \\
\text { objectives/ standards } \\
\text { monitoring } \\
\text { source apportionment } \\
\text { emission inventory } \\
\text { modelling } \\
\text { exposure and health assessment } \\
\text { strategies (i.e. air quality plans) } \\
\text { public participation }\end{array}$} & \multicolumn{3}{|c|}{$\begin{array}{l}\text { 1) Vision } \\
\text { 2) Pathways } \\
\text { 3) Agenda } \\
\text { 4) Experiments } \\
\text { 5) engaging and anchoring } \\
\text { 6) monitoring }\end{array}$} \\
\hline \multicolumn{6}{|c|}{$\downarrow \downarrow \downarrow$} \\
\hline \multicolumn{6}{|c|}{ Urban Context Specificities } \\
\hline \multicolumn{6}{|c|}{$\downarrow \downarrow \downarrow$} \\
\hline \multicolumn{6}{|c|}{ Criteria and features } \\
\hline & Governance & \multicolumn{3}{|c|}{ Instruments } & Techniques \\
\hline $\begin{array}{ll}\text { - } & \text { go } \\
: & \text { soc } \\
: & \text { op } \\
: & \text { sel } \\
: & \text { mu } \\
\text { - } & \text { ind }\end{array}$ & $\begin{array}{l}\text { al inment initiation and leadership } \\
\text { andion and leadership } \\
\text { public involvement } \\
\text { cted stakeholder involvement } \\
\text {-level coordination } \\
\text { i-sectoral coordination } \\
\text { pendent facilitation (science) }\end{array}$ & $\begin{array}{ll}\text { - } & \text { lega } \\
\text { - } & \text { volu } \\
\text { - } & \text { regu } \\
\text { - } & \text { dial } \\
\text { - } & \text { infor } \\
\text { - } & \text { spa } \\
\text { - } & \text { elab } \\
\text { ime } & \text { tims } \\
\end{array}$ & ication & & $\begin{array}{ll}\text { - } & \text { quantitative analysis } \\
\text { - } & \text { qualitative analysis } \\
\text { - } & \text { foresiling and simulation } \\
\text { - } & \text { creativity techniques } \\
& \text { reflexive monitoring }\end{array}$ \\
\hline \multicolumn{6}{|c|}{$\downarrow \downarrow \downarrow$} \\
\hline \multicolumn{6}{|c|}{ Discourses and Outcomes } \\
\hline \multicolumn{6}{|c|}{$\downarrow \downarrow \downarrow$} \\
\hline \multicolumn{6}{|c|}{ Discussion } \\
\hline
\end{tabular}

Fig. 1 Approach for Juxtaposing Urban Air Quality Management with Urban Transition Management. Figure 1 outlines the approach for juxtaposing Urban Air Quality Management (UQAM) with Urban Transition Management (UTM). It highlights that UAQM and UTAM are both process frameworks of urban planning and presents criteria and features that are used for their juxtaposition. This mainly takes place in the case study of UAQM in the EU and the City of Aachen. Therefore, the juxtaposition departs from the context specificities in Aachen. Next, an analysis of UAQM in Aachen is done that is embedded in the EU context and structured along the criteria (governance, instruments, and techniques) and using the related features. Then, a description of discourses and outcomes of UAQM in Aachen is used in order to further investigate whether and how a transformative process has taken place so far. Finally, the discussion juxtaposes UAQM and UTM by a reflection of the case studies' findings on UAQM in relation to UTM. Source: Author, based on Wolfram 2018

Fig. 1). To juxtapose the UTM process presented above with UAQM, the framework by Gulia et al. (2015) will be used. It consists of eight interrelated UAQM elements: 1) objectives/standards, 2) monitoring, 3) source apportionment, 4) emission inventory, 5) modelling, 6) exposure and health assessment, 7) strategies, 8) public participation. This framework is well in line with the EU AAQD, which includes a broad set of similar elements, which in interaction shall improve or maintain ambient air quality (EC 2018; EU 2008). Hence, the UAQM process is also reflected in air quality plans and short term action plans according to this directive (Chapter IV "Plans"; cf. Miranda et al. 2015). These plans are included in element No. 7 of the UAQM framework and can be regarded as air quality 'planning' in a narrow sense, because they focus on the process of measure implementation.

The juxtaposition of UAQM and UTM essentially builds on the framework by Wolfram (2018) introduced above. This is also done in order to ensure consistency with previous research, as well as for comparability with assessments of other urban planning approaches therein. The framework compares urban planning with transition management on the basis of their underlying key features. For the purpose of empirical study, this set 
of criteria needs to be contextualized by describing the actual UAQM process and local specificities, as well as the relevant transformation discourses and outcomes.

\section{Methods}

To the knowledge of the author there is to date no (formal) UAQM process that explicitly uses a UTM approach. An explorative Scopus search (12 Feb 2019) for papers on sustainability transitions (or transformations) and air quality confirmed this assumption. This legitimises the use of a single explorative case study design to answer the research questions (cf. Ridder et al. 2016).

The case study applies the derived framework (Approach for juxtaposing UAQM and UTM section) by redrawing the UAQM process in the urban context of the city of Aachen (Urban context specificities, Governance, instruments and techniques, Discourses and outcomes in Aachen sections) and, by doing so, introduces the UAQM framework more deeply. The findings are discussed in the subsequent section against the background of UTM. Aachen is chosen as case study area for three reasons: Firstly, Aachen was one of the first areas where an air quality plan had to be implemented after the AAQD came into force and it still faces air pollution exceedances, resulting in two revisions of the plan. This allows an investigation of change processes over a ten-year period. Second, since the very beginning the city has claimed to take a unique approach to UAQM ("Aachen Way", Langweg et al. n.d.), which could be interpreted as a transition-like strategy. Third, the analysis can benefit from the author's previous work on the case, both in the air quality field (e.g. PMLab project, see Severijnen 2014) and its intersection with transition research; (e.g. SzaboMüller and Fromhold-Eisebith 2017: Herausforderungen der Sustainability Transitions in Grenzräumen, unpublished). Although Aachen is 'only' a mid-sized city it faces similar problems like larger ones and could represent a good 'laboratory' for the investigation and learning about transition dynamics in relation to UAQM.

Due to its explorative character, the main instrument of the case study is a qualitative document analysis. At its heart are Aachen's 2009 air quality plan and its two revisions in 2015 and 2019. These also reflect the features of the UAQM framework and are further interpreted both as milestones and outcomes of the (local) air quality discourse. In order to go beyond an analysis of official documents and to also reflect the public discourse, selected newspaper articles were included in the analysis as reference (some were used in a discourse analyses in e.g. Szabo-Müller and Fromhold-Eisebith 2017: Herausforderungen der Sustainability Transitions in Grenzräumen, unpublished). Furthermore, the Aachen case is embedded in the Multi-Level Governance setting of EU and national air quality policy. Therefore, where necessary information from the responsible bodies is added, for instance the European Commission, the European Environment Agency (EEA) as well as national and federal state authorities and agencies, respectively. This particularly includes relevant directives (i.e. the EU Ambient Air Quality Directive 2008/50/EC), reports, and websites.

\section{Case study: UAQM in the City of Aachen (Germany)}

\section{Urban context specificities}

The City of Aachen has several context specificities that determine its transformative capacity and its UAQM strategy. It has a population of about 250,000 inhabitants, which is a major city in official German terminology, but is very small in 
global terms. However, the city is a major player in the German and global knowledge economy, particularly due to the Rheinisch-Westfälische Technische Hochschule (RWTH) Aachen University which has 10,000 employees, 45,000 students and had the highest third-party funding rates ( $€ 297$ Mio.) of all German Universities in 2016 (aachen tourist service e.V. 2019; AN 2018; RWTH Aachen University 2018). A further specificity is its location in the three-country triangle of Belgium, Germany and the Netherlands (the so called Euregio Meuse-Rhine), which is important for the city's local identity in addition to its historical heritage (i.e. Charles the Emperor) and the above-mentioned importance of the knowledge economy. Natural specificities that strongly influence local air quality are the local climate and topography (basin) (Merbitz 2013). The trend of air quality concentrations can also be regarded as a part of the urban context. As Fig. 2 shows, the air quality situation in Aachen is characterised by continuous exceedances of the $\mathrm{NO}_{2}$ limit value, while the situation for $\mathrm{PM}_{10}$ has improved. Together these factors caused and shaped the so-called "Aachen Way" (Langweg et al. n.d.) of UAQM, which focuses on long-term, innovation and incentive focused measures, in contrast to the short-term implementation of restrictions such as low-emission zones (LEZ), which for a long time were a preferred strategy in Germany and the federal state of North Rhine-Westphalia (NRW).

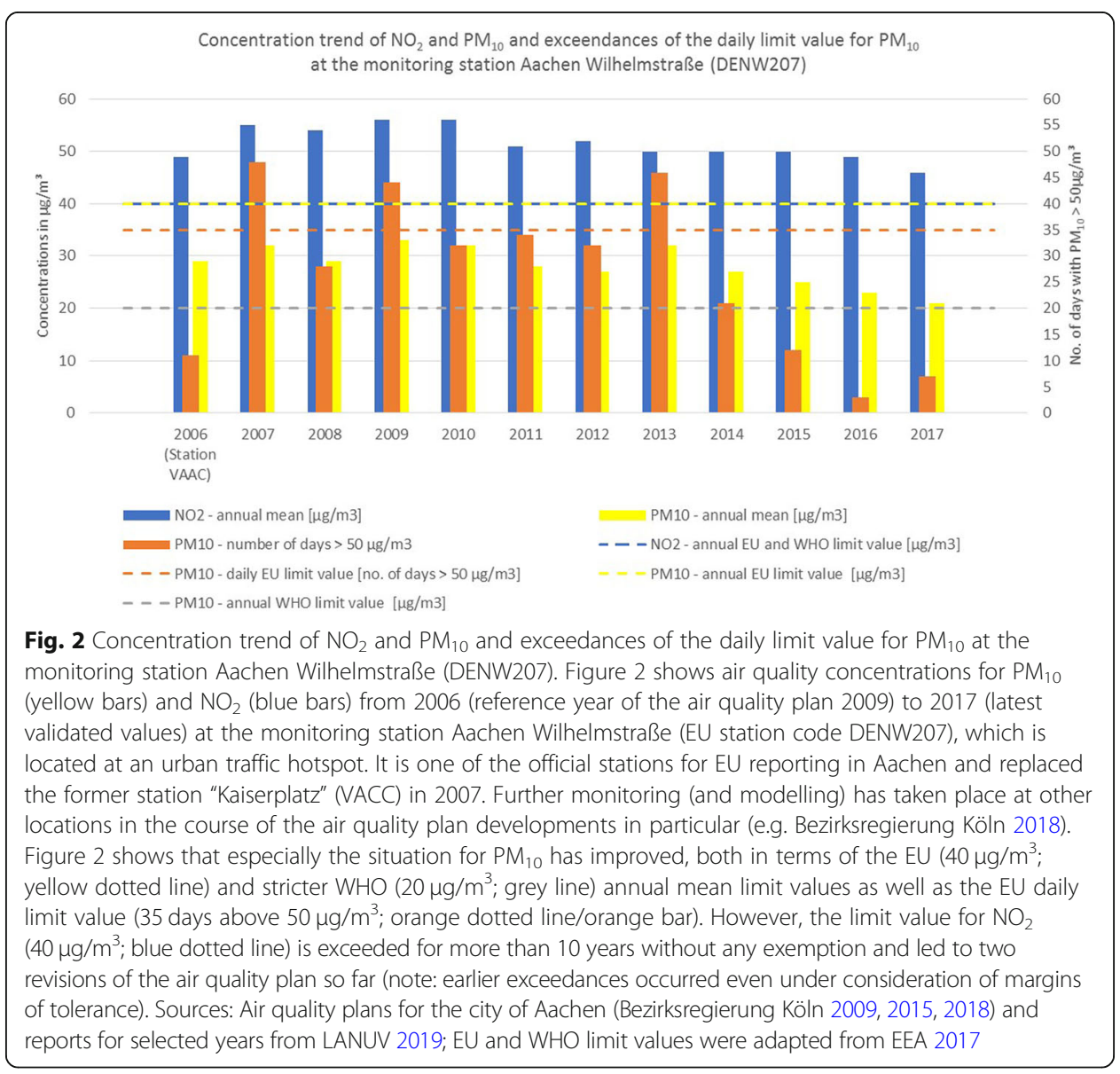




\section{Governance, instruments and techniques}

The following section analyses UAQM in Aachen in terms of the criteria and features of the analysis framework (Fig. 1). Hence, it is basically structured along the eight elements of the UAQM process, which are indicated in parentheses (e.g. UAQM\#1; in Discussion: juxtaposing UAQM and UTM section the same is done for UTM). The corresponding features of governance, instruments and techniques are highlighted in italics where applicable.

The objectives (UAQM\#1) and time frames (i.e. time horizons and elaboration periods) are basically set on the European level and recently framed as three transition-steps (EC 2005; EC 2015, 2016; EEA 2015, 2017; EU 2013): As an outcome of the revision of EU air quality policy in 2013, the "Clean Air Policy Package" picks up the target from 2005 to fully comply with limit values by 2020 ("Thematic Strategy on Air Pollution"), but aims at further improvements to halve the number of premature deaths by 2030. The first was a result of the 6th and is also target of the 7th EU Environment Action Plan, seen as a contribution to its 2050 transition vision of "zero air pollution" (EEA 2015). In general, "[t]he EU's clean air policy framework sets EU air quality standards, implements the EU's international obligations in the field of air pollution, and integrates environmental protection requirements into other productive sectors" (EEA 2017). For the urban context, particularly the AAQD is important. Via this directive (U)AQM is a highly regulated and legally binding approach within the multi-level governance framework of EU air quality policy and hence, mostly characterised by government initiation and leadership. The major strategy instrument to fight against air pollution in Europe are air quality plans and short term action plans (EU 2015) (UAQM\#7). They are formal planning instruments (formal thematic plans in the typology of Wolfram 2018), and stand for air quality 'planning' in a narrow sense. According to the directive, EU member states are obliged to implement air quality plans (Article 23) in case of exceedances of limit values for the protection of human health (AAQD, ANNEX XI; UAQM \#1), partially in line with respective WHO Standards. In Aachen and beyond it is especially those for $\mathrm{PM}_{10}$ (the $10 \mu \mathrm{m}$ aerodynamic diameter fraction of $\mathrm{PM}$ ) and $\mathrm{NO}_{2}$ that shape the public discourse and urban air quality planning (cf. EEA 2018a). The task of air quality plans is to "set out appropriate measures, so that the exceedance period can be kept as short as possible" (AAQD, Article 23), leaving some room for interpretation of what "appropriate measures" or "as short as possible" means in detail. In a similar way, short term action plans (AAQD, Article 24) have to be drawn up in case of (risking) exceedances of alert thresholds, to immediately reduce air pollution concentrations during pollution peaks. Hence, the elaboration periods of air quality and action plans is intended to be a few years, while monitoring (see below) is a rather continuous task.

As indicated previously, UAQM in Aachen is heavily shaped by the national context and the way in which EU policy and law are translated into it (Severijnen 2014). In Germany, air quality policy is characterised by strong subsidiarity and a strong role of the federal states. The national air quality strategy of Germany has been based on four main principles for many years (BMU 2018): i) definition of air quality standards, ii) emission reduction requirements according to the best available technologies, iii) product regulations and iv) definition of emission ceilings. The federal states play a crucial role, because they are responsible for the execution of the AAQD. Therefore, the federal state North Rhine-Westphalia (NRW) is responsible for the Aachen air quality 
plan, which is implemented under coordination and by guidance of the District Authority of Cologne ( cf. Bezirksregierung Köln 2015). So in fact, it is an air quality plan for the urban area of Aachen, but not a plan by the city itself.

A major basis and facilitator for air quality governance and action is the underlying scientific knowledge, but even if both air quality research and policy are interdisciplinary fields, science and engineering seem to be most influential, bringing to mind rationalist planning (cf. Wolfram 2018). This can be seen by the features of UAQM techniques (i.e. UAQM\#2-6). In the Aachen case, these are strongly related to one other crucial federal state actor, the State Agency for Nature, Environment and Consumer Protection (LANUV) that is assigned to the Federal Ministry for Environment, Agriculture, Conservation and Consumer Protection (MULNV). The LANUV is responsible for all official assessment steps and it does so all over the federal state and thereby applies the corresponding planning techniques (reference laboratory according to AAQD). These mainly contain quantitative analyses based on or in terms of, respectively, monitoring station networks, source apportionments, emission inventories, modelling approaches as well as exposure and health assessments (Gulia et al. 2015; Miranda et al. 2015; Thunis et al. 2016a; Thunis et al. 2016b). These serve as (dis-) continuous means of control as well as forecast (not so much foresight) and evaluation tools for abatement measures in terms of limit value compliance. Therefore, the assessments can be regarded as part of a reflexive monitoring process. In fact, the results from applying these techniques and reporting by the LANUV are the basis for the decision on whether an air quality plan has to be implemented or not, and how much reduction has to be achieved, thus (co-) determining somehow which abatement measures are taken. This is also the case in Aachen.

Coming back to governance and air quality strategies (UAQM\#7), again, the development process of the local air quality plan in Aachen is characterised by selected stakeholder involvement. The main instrument for (local) dialogue and negotiation is a work group of experts. They are invited by the District Administration to discuss the features of the air quality plan, particularly the concentration situation and related options for air quality measures. The work group was first set up in the course of the first air quality plan in 2009 and also assisted the two revisions in 2015 and 2019. So the AAQD had an almost immediate impact on local air quality governance in Aachen.

Regarding the systemic scope, a main focus of UAQM on the transport sector can be observed, while air quality management in general is multi-sectoral and achieved a lot of success in other domains (e.g. industry). Today, local road traffic is the main reason for exceedances of $\mathrm{PM}_{10}$ and $\mathrm{NO}_{2}$ limit values and is consequently the focus of UAQM in Aachen and many other European cities (Bezirksregierung Köln 2018; EEA 2018a). However, other sources such as agriculture, shipping, wood burning or industrial facilities can also be of importance in other places. Furthermore, UAQM is embedded in multi-level governance processes and multi-scalar relations that go beyond the local context. The spatial scope of the Aachen air quality plan itself is even below the city scale. For instance, results from monitoring stations at traffic 'hotspots' determine measure implementation. However, there are also several city-wide measures.

The transport focus of UAQM is also reflected by the local multi-stakeholder constellation in the work group and the formal decision making process in Aachen. The city administration is mainly represented by the Department for Environment and the 
Department for Urban Development and Urban Infrastructure (i.e. Division for Traffic Management and Road Authority). Also the regional transport authority and local transport companies take part. Furthermore, several environmental NGOs play an important role in the group and the discourse, as well as business representatives. Hence, several other techniques such as urban and transport planning are also applied by different actors in addition to those of the LANUV. Formal local decision making about measures takes place outside the work group, mostly in the city councils' mobility committee, in some cases in the committee of environment and climate (e.g. energy measures). The plan as a whole is decided by the council.

In Aachen, public involvement (UAQM\#8) in relation to the air quality plan itself has so far taken place mainly in terms of formal public consultations giving the possibility of commenting on the draft air quality plan. This is in accordance with the requirements of AAQD Chapter V (cf. EEA 2019). Furthermore, some measures in the plan focus on or include information and communication aspects, respectively. If more intensive participation took place, this was mainly in the course of specific projects or plans related to the air quality plan. After having outlined the process and major features of UAQM the question is how it actually unfolded a transformative discourse, and which outcomes it had in Aachen.

\section{Discourses and outcomes in Aachen}

Almost immediately after the EU AAQD came into force in 2008, an air quality plan had to be implemented for the City of Aachen in 2009 (Bezirksregierung Köln 2009). Right from the beginning there has been a conflict about strategic preferences that is also rooted in different views of suitable time horizons and elaboration periods of measure implementation. On one hand, there was short-term focused implementation of low emission zones (LEZ). This was a preferred measure in many cities in Germany and Europe at that time, also by the federal government of NRW and the district authority Cologne. On the other hand, there has been the long-term strategy of local actors that was labelled the "Aachen Way" (Langweg et al. n.d.), which included a package of measures that mainly aimed at a shift to sustainable transport modes, but also included some measures in the energy domain. A 'dramatic' turning point in the air quality planning process was the failure of the flagship measure "Campusbahn", which was an integrated tramway and e-mobility project. It was rejected in a local referendum that was initiated by a citizen campaign against the project that - despite substantial national funding - 'successfully' focused on the relatively high costs (cf. AN 2013). In fact, this decision led the "Aachen Way" to break down somewhat - as did the consensus between the actors.

In the following years in particular the limit values for $\mathrm{NO}_{2}$ have been exceeded continuously (in 2013 also for $\mathrm{PM}_{10}$, Fig. 2). In consequence, the air quality plan had to be revised in 2015 (Bezirksregierung Köln 2015) and the local discourse about air quality and the LEZ revitalised. The obligatory revision of the air quality plan also rekindled the basic conflict from the first plan. However, in the meantime advocacy coalitions had changed (AN 2014). On one side were now the district authority (with backing of the federal Ministry for Environment) and a coalition of local environmental NGOs. They no longer trusted the city's politics due to experiences with the failed Campusbahn project and further deficits in measures implementation. On the other side, city and business actors argued jointly against the LEZ implementation, mainly by repeating 
former arguments that it would negatively affect local business and retailing (i.e. business related transport activities, barrier for visitors from Belgium and Netherlands), while having no significant positive effect on air quality at all. Given this situation in combination with the failed limit value compliance, the 'danger' of a LEZ was even higher than before. Hence, city actors were heavily pushed to 'update' their measure package, also due to pressure from the EU Commission on the national government that trickled down to the urban area (AN 2015). The result was that this time the LEZ had to be implemented in the beginning of 2016, but also the 'alternative' measure package was adopted. Paradoxically, public transport buses were identified as a major contributor to air pollution concentrations and thus were in focus of the 2015 revision. Hence, the LEZ implementation mostly served as a legal enforcement instrument for retrofitting of buses, since most private cars were already in line with the relevant Euro Norms and got a green environmental badge. However, because of the so called "Dieselgate" affair the underlying assumption of 'clean' cars was rather theoretical.

Already in the development phase of the first revision of the air quality plan, details became (and still become) public about car engine software manipulations by Volkswagen and other car manufacturers. The use of illegal defeat devices was compounded by insufficient type approval procedures on test stands and led to higher real world $\mathrm{NO}_{\mathrm{x}}$ emissions of diesel cars than expected. However, a disconnection of test stand and real-world emissions occurs even without manipulations (Barnes et al. 2018; UBA 2018). In order to close this gap, new testing standards were implemented recently in the EU in terms of "realdriving emissions" (RDE) in combination with improved laboratory tests (EC 2017).

The "Dieselgate" affair and the failure of the Euro standards set under the type approval tests currently shape the discourse at all political levels and in several domains (e.g. environment, transport and industry). In particular, lawsuits by the German Environmental Defense (DUH) that aim at enforcing diesel bans in several German cities and related decisions by the German Federal Administrative Court as well as the local administrative court in Aachen led to the second revision of the air quality plan in Aachen in 2019 (Bezirksregierung Köln 2018). This was both due to further limit value exceedances for $\mathrm{NO}_{2}$, but also because of continuous shortcomings in measure implementation. Similarly to the situation in 2009 and 2015, the fear about and opposition to a diesel driving ban led to more ambitious local action, also in terms of realising lagging measure implementation from the 2015 plan. This time a crucial difference occurred in the air quality planning process: Contrary to the LEZ implementation, the target of avoiding diesel driving bans on the local level was well in line with the respective national and federal government's policy. Therefore, both provide more directed funding for urban air pollution abatement, which was previously lacking (i.e. federal 'emergency clean air programme' (2017-2020), "zero emission city centers" NRW; cf. Bezirksregierung Köln 2018). The City of Aachen adapted its measure package from 2015. It put greater weight on those elements that already pointed in this direction, to ensure fast(er) implementation of these programmes. Hence, the following "most effective and fast to implement measures" (Bezirksregierung Köln 2018) are given priority: i) retrofitting of buses with SCRT-filtration; ii) better coordination and raising of parking fees to reduce parking space search traffic; iii) more ambitious emission standards for buses in the local transport masterplan; and finally, iv) software updates for manipulated cars and 'switchover bonuses' for replacing older diesel cars with 
newer models (provided by car manufacturers/on the national level). Assessments in the air quality plan confirmed these measures to be sufficient for limit value compliance, or in other words, access restrictions in terms of route specific diesel driving bans, a blue low emission zone etc. were rejected and said to be disproportionate (Bezirksregierung Köln 2018). Another argument is the expectation of further positive effects on local air quality in Aachen from the translation of the revised EU Air Quality Policy (Clean Air Policy Package) into national law. As an intermediate result, a diesel ban could be avoided in Aachen, but the question remains as to whether measures will be sufficient for limit value compliance in the near future, or if the history of the first two air quality plans will repeat itself. A final court decision by the Münster Higher Administrative Court will follow in spring 2019 (cf. AN 2019).

\section{Discussion: juxtaposing UAQM and UTM}

\section{How transformative is current UAQM?}

This section compares UAQM and UTM in more detail. Table 1 summarises the main findings gained to this point and is structured by the criteria and features of the analysis framework (urban planning is only added for information purposes here; for its comparison with transition management see Wolfram 2018). Together with Fig. 1 it gives orientation for the following discussion as well.

Discourses and outcomes of the UAQM process in the EU and Aachen show typical characteristics of an unfolding transition (i.e. interactions of regimes, landscape and niches). However, the case study in Aachen indicates similarities of UAQM and UTM to be rather coincidental, perhaps because UAQM is part of the transition itself, but so far it is not an intended transition governance approach. On a first superficial view,

Table 1 Comparison of urban planning, transition management and air quality management

\begin{tabular}{|c|c|c|c|c|}
\hline & & $\begin{array}{l}\text { Urban } \\
\text { Planning }\end{array}$ & $\begin{array}{c}\text { Transition } \\
\text { Management }\end{array}$ & $\begin{array}{c}\text { Urban } \\
\text { Air Quality Management }\end{array}$ \\
\hline \multirow{7}{*}{ 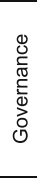 } & government initiation and leadership & ** & * & ** \\
\hline & social initiation and leadership & & ** & \\
\hline & open public involvement & ** & & \\
\hline & selected stakeholder involvement & ** & ** & ** \\
\hline & multi-level coordination & * & ** & ** \\
\hline & multi-sectoral coordination & * & ** & ${ }^{*}\left({ }^{*}\right)$ \\
\hline & independent facilitation (science) & & ** & $*^{*}\left({ }^{*}\right)$ \\
\hline \multirow{10}{*}{ 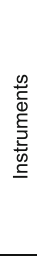 } & legally binding & ** & & ** \\
\hline & voluntary commitment & * & ** & \\
\hline & regulation & ** & & ** \\
\hline & economic cost/ benefit & ${ }^{*}$ & & * \\
\hline & dialogue and negotiation & ** & ** & * \\
\hline & information and communication & * & ** & * \\
\hline & spatial scope & ** & $\left({ }^{* \star}\right)^{1}$ & ** \\
\hline & systemic scope & * & $* *$ & $*^{*}\left({ }^{*}\right)$ \\
\hline & elaboration period (years) & $1-5$ & $1-5$ & $1-2$ \\
\hline & time horizon (years) & $1-20$ & $1-50$ & $1-10 / 20$ \\
\hline \multirow{6}{*}{ 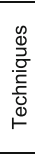 } & quantitative analysis & ** & ** & ** \\
\hline & qualitative analysis & * & ** & \\
\hline & modelling and simulation & ** & ** & ** \\
\hline & foresight techniques & * & ** & \\
\hline & creativity techniques & * & ** & \\
\hline & reflexive monitoring & * & ** & ** \\
\hline & \multirow{4}{*}{$\begin{array}{r}\text { Key } \\
\text { Pertinance of features }\end{array}$} & & & \\
\hline & & & \multirow{3}{*}{\multicolumn{2}{|c|}{$\begin{array}{l}\text { low } \\
\text { average } \\
\text { high } \\
\text { unclear (colour according to lower value) }\end{array}$}} \\
\hline & & ** & & \\
\hline & & ( ) & & \\
\hline & \multicolumn{4}{|c|}{$\begin{array}{l}\text { Notes: 1) spatial scope of Urban Transition Management assessed high; } \\
\text { Transition Management in general assessed low in Wolfram } 2018\end{array}$} \\
\hline
\end{tabular}


elements such as the reflexive design of the air quality plan (assessments, evaluations etc.), the definition of limit values, the selective participatory approach (i.e. the expert work group) and the mostly long-term oriented measures aiming at a shift to sustainable transport look rather similar to some elements of UTM (TM cycle as such; agenda, arena, experiments, monitoring and evaluation etc.). Much like UTM, UAQM is also a multi-scale, multi-sector as well as multi-actor process both by design and due to the actual characteristics of transitions. Both UTM and UAQM combine analytical and operational tools. On a second more detailed view, however, there are substantial differences. Actually, the starting points and targets differ and, hence, what is done and how. UAQM aims at effectively (and measurably) protecting public health on a legal basis of an EU Directive and 'as soon as possible', while transition management aims at longterm sustainable innovation, mostly by short-term and voluntary experimentation and social learning. Consequently, monitoring and evaluation may also relate to different targets (UAQM\#2-6, UTM\#6) and thus be carried out in different ways. All in all, UAQM and UTM are rather complementary, yet although each approach has strengths (and weaknesses) in itself, it is not sufficient for achieving the targeted transition alone.

The Aachen case seems to be in between both approaches. Together with context specificities (e.g. RWTH Aachen) the opposition against the LEZ led to the "Aachen Way" as a kind of transition vision (UTM\#1) for sustainable urban mobility. Therefore the traffic development plan, which uses the Sustainable Urban Mobility Plan (SUMP) approach (EU 2019), is a central measure but has failed so far, too.

And even if experimentation and social learning (e.g. UTM\#4) is normally not at the forefront of UAQM, it has taken place in the course of the first plan implementation in 2009 and its two revisions in 2015 and 2019. Besides already mentioned failures, the air quality plan itself delivered an agenda (UTM\#3) and room for niche experimentation and innovation. The 'danger' of a LEZ and later diesel driving bans created pressure and a local spirit of action, and allowed designing measures which probably would not have been possible that way before, particularly in the transport domain, where local politics have been car favouring for many years. Since the first plan, a pathway (UTM\#2) of new qualities and upscaling in several fields of action can be observed. For example, changes in promotion of biking from small bike lanes to plans for a major bike road network and biking highway, promotion of public transport from 'clean' diesel buses to electric buses and/or experimenting with autonomous buses, while car and bike sharing get both upscaled and 'electrified'. Also business has benefited from this context, for example Cambio Carsharing, e.go (e-car), streetscooter (a well-known e-transporter, now owned by the German Post/DHL) and velocity (e-bike sharing), which weakens arguments that UAQM would threaten local business. However, limit value monitoring proves these measures to be little more than experiments so far (with the existing car regime continuing to dominate). Backlashes such as the failed Campusbahn project also occurred. Furthermore, as can be seen from the list of measures, like in other places UAQM in Aachen has a rather techno-centric focus, despite claiming for incentives or at least assuming long-term behavioural change, respectively. While the reasons behind this observation are open to future research, a transition based UAQM could perhaps lead a better balance of social and technical innovations for air pollution. While one can argue that UTM is a pro-active approach, UAQM however is quite reactive, i.e. limit value exceedances give a significant push for measure 
implementation. Also the work group in Aachen acts mostly in response to limit value exceedances, while participants themselves work more continuously on air quality issues in their respective domain. In fact and as described in Introduction: air pollution and urban air quality management (UAQM) section, it is hard for policy makers to legitimate any action 'beyond' limit value compliance, even if the difference is minimal. At first, this is in contradiction with transition thinking and aggravates engaging and anchoring (UTM\#5). The same can be said with regard to the target of public health protection, because there seem to be no thresholds where for instance $\mathrm{PM}$ and $\mathrm{NO}_{2}$ do no harm (Barnes et al. 2018). Perhaps UTM could become a tool for more pro-active, health oriented UAQM as argued for by Brunt et al. (2018) for example. Furthermore, it could help to tackle the multitude of harmful "non-regulated pollutants", for which no standards are yet defined (e.g. particle number, black carbon, ozone precursors; EEA 2019). All this should also be considered in relation to the SDGs, where mitigating (urban) air pollution and creating co-benefits are central targets worldwide (see Introduction: air pollution and urban air quality management (UAQM) section). Finally, the Aachen case shows a kind of 'transition paradox' and reveals the importance of a double strategy of niche promotion and pressure on the regime. The "Aachen Way" was and is more regime friendly than intended, because it takes pressure off the actual car/combustion engine regime instead of putting pressure on it through the restrictions of a LEZ or diesel driving ban. These could have opened up even more space for the emergence and upscaling of sustainable transport niches. Perhaps a transition based UAQM-design could have helped here. However, in reality all UAQM elements are currently contested in relation to the (inter-) national "Dieselgate" affair. On one side, car regime actors argue, for example, that limit values are too ambitious, health effects are questionable, or that the car industry has to be protected. On the other side, air quality and health (and hence UAQM) are aggressively defended by niche actors such as the German Environmental Defence or local NGOs. From a policy point of view, recent programmes by the national and federal state may look ambitious and transformative on a first view. However, for example assessments in the 2019 Aachen air quality plan proved measures from the federal "zero emission city center" programme to be without effect on air pollution in the short-term. On the national level the "lead cities" approach appears to be a kind of urban lab approach, but seems to lag behind activities in Aachen and other places. All in all, Aachen and other cities seem to be "squeezed" (de Haan and Rotmans 2011) by multiple transition dynamics.

\section{How can UAQM and UTM be combined?}

Due to the described commonalities and differences, the case of air quality really supports the proposition of several authors to see urban planning and urban transition management as approaches that complement - but do not replace - one another (Nevens et al. 2013; Wittmayer and Loorbach 2016; Wolfram 2018). But how can both process models complement each other? For instance, Turnheim et al. (2015) and similarly Geels et al. (2016) proposed to bridge and link Integrated Assessment Modelling (IAM), socio-technical transition theory and practice-based action research, both for better analysis and better governance of low-carbon transitions. All of these approaches are welcome 'docking points' for 'urban air quality transition management'. First, IAM 
is a well-established air quality assessment method and offers opportunities for joint engagement of the air quality and transition communities as well as the translation of transition thinking and knowledge (and hence the underlying values) into UAQM. Second, a major assumption of socio-technical transition theory is that a better understanding of systems leads to better system governance (Grin et al. 2017). Consequently, this also applies to 'air quality transitions' on an urban-regional scale, where for example transition pathways based discourse analysis can be a valuable tool for both (e.g. Szabo-Müller and Fromhold-Eisebith 2017: Herausforderungen der Sustainability Transitions in Grenzräumen, unpublished). Third, UTM and particularly urban transition labs are in fact approaches of practice-based action research. However, there is so far no (formal) UAQM process using an explicit transition management approach or urban transition lab as a setting. But in the EU and beyond there is a promising trend of citizen sensing and related living lab-like approaches, enhanced by low-cost monitoring equipment (AiREAS 2016; CAPTOR 2018; Curieuzeneuzen Vlaanderen 2018; hackAIR 2018; Jiang 2017; luftdaten.info 2018; RIVM 2018). This could result in tackling air pollution more at its roots (e.g. individual needs, preferences and behaviour) and not so much by technological 'end-of-pipe' measures. In the Aachen case, for example, citizen sensing could be used in a coordinated dialectic way (cf. Wolfram 2018) that keeps the closed 'expert transition arena' with selected frontrunners alive, while creating a complementary 'citizen transition arena' for open public participation and action.

Furthermore, UAQM is both embedded and reflects actual air quality policy designs like that of the EU and particularly the AAQD. To overcome potential policy disconnections (Barnes et al. 2018), an ideal 'multi-level air quality transition management' could be carried out in one joint transition management cycle, where tasks are shared according to the best fitting level (i.e. subsidiarity principle). Alternatively or in addition, multiple local-regional (and sectoral) TM cycles could work on solutions for better air quality, in partially coordinated or independent ways. For example, long-term and large scale objectives could be defined at higher levels (e.g. EU, WHO, national governments), ideally in coordination with the lower levels (e.g. cities, regions), who will define their own transition agenda and pathways that contribute to high-level goals or follow even more ambitious ones. Theoretically, EU air quality policy already allows for this. However, reality is still far away from this, as for instance the 'management' of the "Dieselgate" affair in Germany revealed. In the face of rapid global urbanisation, however, small and mid-sized cities such as Aachen, as well as districts of large and/or Megacities with a similar size, could serve as laboratories for experimenting and learning from the suggested approaches.

Finally, limit values will still play a crucial role in UAQM and also in the further transition. On the one hand, limit values are in principle a good guide on the transition pathway and compliance with them is a necessary interim step, but are not yet sufficient (e.g. EU vs. WHO limit values, non-regulated pollutants). On the other hand, UAQM should be both designed to achieve better health in the short- and mediumterm and to work on a more ambitious transition in the long-term (cf. EEA 2015). However, the first requires already big steps and not only 'radical change in small steps' as proposed by sustainability transition research. Otherwise there is the danger of getting lost in experimentation without generating the impacts needed urgently (cf. Hölscher 2018). 


\section{Conclusions}

Air pollution and its health effects are major sustainability challenges worldwide and hence addressed by the UN SDGs. The EU Ambient Air Quality Directive (2008/50/ EC) is arguably one of the most advanced policy frameworks for tackling air pollution and has achieved a harmonisation of urban air quality management (UAQM) in EU Member States to a large extent. Most importantly, the directive includes obligations for the implementation of air quality plans in case of limit value exceedances. However, exceedances still occur in many cities more than ten years after the directive came into force. In parallel, sustainability transition research and urban transition management (UTM) have emerged in Europe, too. Through the case of the City of Aachen (Germany), this paper has sought to explore whether UAQM as an example for an established and widely applied environmental planning approach could be enhanced by combining it with the emerging UTM approach. The case study revealed that UAQM and UTM seem to have many similarities on a first view (e.g. selected stakeholder participation, evaluation and monitoring), but differ significantly in detail (e.g. targets, time frames, degree of commitment, experiments vs. measures). Therefore they are mostly complementary, but due to their respective strengths and weaknesses would require better integration and combination to achieve the targeted transition.

The juxtaposition of the two approaches also opens up directions for future research that may help overcome the limitations of this paper. First, comparative analyses are necessary in order to go beyond this explorative single case study, which could be used as a benchmark. Ideally, this should be enhanced by transformative research approaches at the intersection of research and practice, for instance by implementing 'urban air quality transition management labs' in selected cities. Here, the best fitting instruments of UTM and UAQM for the respective context could be selected, applied and monitored regarding their transformative potential. For instance, citizen sensing may play a crucial role here, but also Integrated Assessment Modelling (IAM) and socio-technical transition analysis. It should be investigated whether and how the potential of transformative UAQM could be realised, how continuous engagement could be achieved, and also whether this approach is more effective than conventional UAQM. The comparative lab approach should further investigate how to align air quality related transition pathways at different scales (both in space and time), and how to assure consistency as well as coordination of the respective dynamics. Recent developments of EU air quality policy such as the implementation of new directives in the course of the Clean Air Policy Package should also be considered. Another obvious limitation of this study is that air pollution is without a doubt a major urban sustainability challenge, but it is by no means the only one. However, as cities worldwide are facing urgent problems with air pollution, the issue of air quality could well be used for piloting urban transition management in general. A combined approach of UAQM and UTM could be used right from the outset, especially where environmental governance structures are insufficient and/or even have to be newly developed, considering for example Megacities in the Global South.

Regarding policy recommendations, at least two points are crucial for realising 'urban air quality transition management'. First, to date UAQM is to a great extent a task of implementation and enforcement of law, which provides public authorities' legitimation for action, whereas UTM is a voluntary activity. Hence, 'urban air quality transition 
management' should be facilitated legally, if not even obliged ('transition by law'), for example by more specific participation requirements in the Ambient Air Quality Directive, clearly going beyond information obligations. Second, to facilitate and ensure action until and also beyond limit value compliance, local actors need a long-term vision and reliable financial resources, supported by all political levels, as well as by business and society. Transformation funds and a "normative compass", as proposed by the WBGU (2016), could effectively help to realise ambitious air quality plans, while providing orientation for the vision and broader legitimation on the pathway to sustainability. All in all, in order to overcome the gap between efficiently organised UAQM and effective protection of people's health a more intensive connection of UAQM und UTM should be strived for in close cooperation between science and practice.

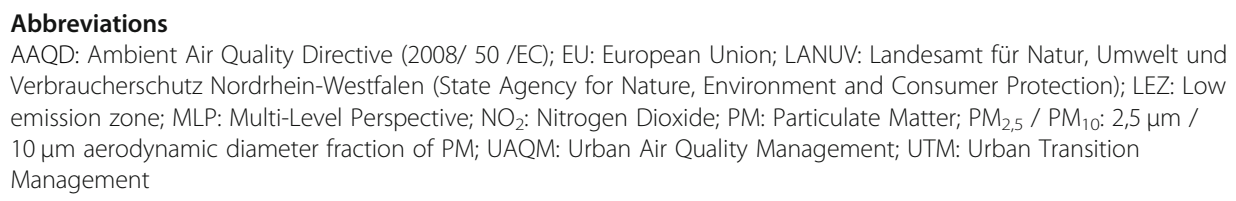
Verbraucherschutz Nordrhein-Westfalen (State Agency for Nature, Environment and Consumer Protection); LEZ: Low emission zone; MLP: Multi-Level Perspective; $\mathrm{NO}_{2}$ : Nitrogen Dioxide; PM: Particulate Matter; PM 2,5 / PM 10 : $2,5 \mu \mathrm{m} /$ $10 \mu \mathrm{m}$ aerodynamic diameter fraction of PM; UAQM: Urban Air Quality Management; UTM: Urban Transition Management

\section{Acknowledgements}

The author would like to thank an anonymous reviewer, the special issue editor and Michael Parker-Bray for their valuable comments and proofreading of earlier versions of the manuscript, as well as BMC for making the publication possible.

\section{Author's contributions}

The author read and approved the final manuscript.

\section{Author's information}

Not applicable.

Funding

Not applicable.

\section{Availability of data and materials}

Not applicable.

\section{Competing interests}

The author declares that he has no competing interests.

Received: 8 March 2019 Accepted: 9 October 2019

Published online: 18 November 2019

\section{References}

aachen tourist service e.V. aachen tourist service. 2019. https://www.aachen-tourismus.de/en/. Accessed 25 Oct 2019. AiREAS. Over AiREAS | AiREAS on WordPress.com. 2016. https://aireas.wordpress.com/about/. Accessed 8 Mar 2016.

AN - Aachener Nachrichten. Aachen: Glasklares Nein zur Aachener Campusbahn. 2013. https://www.aachener-nachrichten. de/lokales/aachen/glasklares-nein-zur-aachener-campusbahn_aid-26205245. Accessed 25 Feb 2019.

AN - Aachener Nachrichten. Aachen: Streit um die Umweltzone schwelt weiter. 2014. https://www.aachener-nachrichten.de/ lokales/aachen/streit-um-die-umweltzone-schwelt-weiter_aid-31323461. Accessed 25 Feb 2019.

AN - Aachener Nachrichten. Grüne Umweltzone wird nicht ausreichen; EU fordert weit stärkere Anstrengungen zur Luftreinhaltung als bisher. Das wird auch Auswirkungen in Aachen haben. Aachen: AN - Aachener Nachrichten (AN); 2015.

AN - Aachener Nachrichten. Forschungsprojekte: RWTH Aachen kassiert die meisten Drittmittel. 2018. https://www.aachenernachrichten.de/nrw-region/rwth-aachen-kassiert-die-meisten-drittmittel_aid-33720859. Accessed 31 Oct 2018.

AN - Aachener Nachrichten. Rote Karte für Dieselfahrer: Die Aachener müssen noch etwas zittern. 2019. https://www. aachener-nachrichten.de/lokales/aachen/ob-es-in-aachen-fahrverbote-geben-wird-entscheidet-sich-im-fruehjahr_aid-3541 9355. Accessed 25 Feb 2019.

Avelino F, Grin J. Beyond deconstruction. a reconstructive perspective on sustainability transition governance. Environ Innov Soc Transit. 2017;22:15-25. https://doi.org/10.1016/j.eist.2016.07.003.

Barnes JH, Hayes ET, Chatterton TJ, Longhurst JWS. Policy disconnect: a critical review of UK air quality policy in relation to EU and LAQM responsibilities over the last 20 years. Environ Sci Pol. 2018:85:28-39. https://doi.org/10.1016/j.envsci.2018.03.024

Bezirksregierung Köln. Integrierter Luftreinhalte- und Aktionsplan der Bezirksregierung Köln für das Stadtgebiet Aachen vom 01.01.2009. 2009.

Bezirksregierung Köln. Luftreinhalteplan für das Stadtgebiet Aachen: 1. Fortschreibung 2015. 2015.

Bezirksregierung Köln. Luftreinhalteplan für das Stadtgebiet Aachen: 2. Fortschreibung 2019 - Entwurf. 2018.

BMU - Bundesumweltministerium. What is air pollution control about?. 2018. https://www.bmu.de/en/topics/air-mobilitynoise/air-pollution-control/general-information/. Accessed 29 Oct 2018. 
Brunt H, Barnes J, Longhurst JWS, Scally G, Hayes E. Enhancing local air quality management to maximise public health integration, collaboration and impact in Wales, UK: a Delphi study. Environ Sci Pol. 2018;80:105-16. https://doi.org/10. 1016/j.envsci.2017.11.014.

CAPTOR. CAPTOR project. 2018. https://www.captor-project.eu/en/. Accessed 19 Mar 2018.

Coenen L, Truffer B. Places and spaces of sustainability transitions: geographical contributions to an emerging research and policy field. Eur Plan Stud. 2012;20:367-74. https://doi.org/10.1080/09654313.2012.651802.

Curieuzeneuzen Vlaanderen. CurieuzeNeuzen Vlaanderen: 20.000 citizens measure air quality. 2018. https://curieuzeneuzen. be/in-english/. Accessed 31 Oct 2018.

de Haan J, Rotmans J. Patterns in transitions: understanding complex chains of change. Technol Forecast Soc Chang. 2011;78: 90-102. https://doi.org/10.1016/j.techfore.2010.10.008.

EC - European Comission. Thematic strategy on air pollution. 2005. http://europa.eu/legislation_summaries/environment/air_ pollution/128159_en.htm. Accessed 15 Mar 2015.

EC - European Commission. Questions and answers on the EU Clean Air Policy Package. 2013. http://europa.eu/rapid/pressrelease_MEMO-13-1169_en.htm. Accessed 15 Mar 2015.

EC - European Commission. Environment action programme to 2020 - Environment - European Commission. 2015. http://ec. europa.eu/environment/action-programme/. Accessed 28 Feb 2016.

EC - European Commission. Air - Policies - Environment - European Commission. 2016. http://ec.europa.eu/environment/air/ index_en.htm. Accessed 4 Aug 2016

EC - European Commission. New and improved car emissions tests become mandatory on 1 September: Press release. 2017. http://europa.eu/rapid/press-release_IP-17-2822_en.htm. Accessed 7 July 2019.

EC - European Commission. Air quality - Introduction. 2018. http://ec.europa.eu/environment/air/quality/index.htm. Accessed 1 Oct 2018.

EEA - European Environment Agency. The European environment - state and outlook 2015: synthesis report.2015.

EEA - European Environment Agency. Air quality in Europe 2017 (EEA Report 13/2017); 2017. https://doi.org/10.2800/850018. Accessed 12 Oct 2017

EEA - European Environment Agency. Improving Europe's air quality - measures reported by countries: Briefing no. 9/2018. 2018a. https:/www.eea.europa.eu/themes/air/improving-europe-s-air-quality/improving-europe-s-air-quality. Accessed 5 Sept 2018.

EEA - European Environment Agency. Challenges for achieving clean air - lessons from ten cities across Europe. 2018b. https://www.eea.europa.eu/highlights/challenges-for-achieving-clean-air. Accessed 2 July 2019.

EEA - European Environment Agency. Europe's urban air quality: Re-assessing implementation challenges in cities EEA Report No 24/2018. 2019

Egermann M, Hutter G. Perspektiven für die Annäherung der Raum- und Transitionforschung - am Beispiel des EU-Projekts ARTS. pnd online 2014; 2014.

Ehnert F, Kern F, Borgström S, Gorissen L, Maschmeyer S, Egermann M. Urban sustainability transitions in a context of multilevel governance: a comparison of four European states. Environ Innov Soc Transit. 2018;26:101-16. https://doi.org/10. 1016/j.eist.2017.05.002.

EU - European Union. Directive 2008/50/EC of the European Parliament and of the Council of 21 May 2008 on ambient air quality and cleaner air for Europe. Official Journal of the European Union (L 152/1). 2008. https://eur-lex.europa.eu/legalcontent/EN/ALL/?uri=CELEX\%3A32008L0050.

EU - European Union. Cleaner air for Europe: directive 2008/50/EC of the European Parliament and of the Council of 21 May 2008 on ambient air quality and cleaner air for Europe. 2015. https://eur-lex.europa.eu/legal-content/EN/LSU/?uri= CELEX:32008L0050\&qid=1533032579173. Accessed 31 July 2018

EU - European Union Mobility Plans: Eltis. 2019. https://www.eltis.org/mobility-plans. Accessed 25 October 2019

Frantzeskaki N, Hölscher K, Bach M, Avelino F, editors. Co-creating sustainable urban futures: a primer on applying transition management in cities. Future city, vol 11. Cham: Springer International Publishing; 2018a.

Frantzeskaki N, Hölscher K, Wittmayer JM, Avelino F, Bach M. Transition management in and for cities: introducing a new governance approach to address urban challenges. In: Frantzeskaki N, Hölscher K, Bach M, Avelino F, editors. Co-creating sustainable urban futures: a primer on applying transition management in cities, vol 11. Cham: Springer International Publishing; 2018b. p. 1-40.

Geels FW. The multi-level perspective on sustainability transitions: responses to seven criticisms. Environ Innov Soc Transit. 2011;1:24-40. https://doi.org/10.1016/j.eist.2011.02.002.

Geels FW, Berkhout F, van Vuuren DP. Bridging analytical approaches for low-carbon transitions. Nat Clim Chang. 2016;6:57683. https://doi.org/10.1038/nclimate2980.

Grin J, Frantzeskaki N, Castán Broto V, Coenen L. Sustainability transitions and the city: linking to transition studies and looking forward. In: Frantzeskaki N, Castán Broto V, Coenen L, editors. Urban sustainability transitions. 1st ed. New York: Routledge; 2017. p. 359-67.

Gulia S, Shiva Nagendra SM, Khare M, Khanna I. Urban air quality management-a review. Atmos Pollut Res. 2015;6:286-304. https://doi.org/10.5094/APR.2015.033.

hackAIR. hackAIR - Open technology platform to access, collect and improve information on air quality - Collective awareness for air quality. 2018. http://www.hackair.eu/. Accessed 19 Mar 2018

Hölscher K. So what? Transition management as a transformative approach to support governance capacities in cities. In: Frantzeskaki N, Hölscher K, Bach M, Avelino F, editors. Co-creating sustainable urban futures: a primer on applying transition management in cities. Cham: Springer International Publishing; 2018.

Jiang X. Large-scale air quality monitoring in smart and sustainable cities. In: Song H, Srinivasan R, Sookoor T, Jeschke S, editors. Smart cities: foundations, principles, and applications. Hoboken: Wiley; 2017. p. 725-53.

Kronsell A, Mukhtar-Landgren D. Experimental governance: the role of municipalities in urban living labs. Eur Plan Stud. 2018; 26:988-1007. https://doi.org/10.1080/09654313.2018.1435631.

Langweg A, Meiners K, Müller U. Der Aachener Weg: Mobilitätsmanagement statt Umweltzone. n.d.. Accessed 23 Aug 2016.

LANUV - Landesamt für Natur, Umwelt und Verbraucherschutz (LANUV) NRW. Jahreskenngrößen und Jahresberichte. 2019. https:/www.lanuv.nrw.de/umwelt/luft/immissionen/berichte-und-trends/jahreskenngroessen-und-jahresberichte. Accessed 8 July 2019 
Loorbach D, Rotmans J. The practice of transition management: examples and lessons from four distinct cases. Futures. 2010; 42:237-46. https://doi.org/10.1016/j.futures.2009.11.009.

Loorbach D, Wittmayer JM, Shiroyama H, Fujino J, Mizuguchi S, editors. Governance of urban sustainability transitions: European and Asian Experiences, 1st ed. Theory and practice of urban sustainability transitions. Tokyo: Springer Japan; 2016. p. s.l.

luftdaten.info. luftdaten.info - Feinstaub selber messen - Open Data und Citizen Science aus Stuttgart. 2018. https:// luftdaten.info/. Accessed 23 Feb 2018

Markard J, Raven R, Truffer B. Sustainability transitions: an emerging field of research and its prospects. Res Policy. 2012;41: 955-67. https://doi.org/10.1016/j.respol.2012.02.013.

Marvin S, Bulkeley H, Mai L, McCormick K, Palgan W. Introduction. In: Marvin S, Bulkeley H, Mai L, McCormick K, Palgan YV, editors. Urban living labs: experimentation with city futures. London, New York: Routledge Taylor; 2018a. p. 1-17.

Marvin S, Bulkeley H, Mai L, McCormick K, Palgan W, editors. Urban living labs: experimentation with city futures. London, New York: Routledge Taylor; 2018b.

Merbitz H. Untersuchung und Modellierung der raumzeitlichen Variabilität urbaner und regionaler Feinstaubkonzentrationen. Dissertation / PhD Thesis; 2013

Miranda A, Silveira C, Ferreira J, Monteiro A, Lopes D, Relvas H, Borrego C, Roebeling P. Current air quality plans in Europe designed to support air quality management policies. Atmos Pollut Res. 2015;6:434-43. https://doi.org/10.5094/APR.2015.048.

Nevens F, Frantzeskaki N, Gorissen L, Loorbach D. Urban transition labs: co-creating transformative action for sustainable cities. J Clean Prod. 2013;50:111-22. https://doi.org/10.1016/j.jclepro.2012.12.001.

EU 2013. Decision No 1386/2013/EU of the European Parliament and of the Council of 20 November 2013 on a General Union Environment Action Programme to 2020 - Living well, within the limits of our planet. Official Journal of the European Union (L 354/171). 2013. http://eur-lex.europa.eu/legal-content/EN/TXT/PDF/?uri=CELEX:32013D1386\&from=EN

Ridder H-G, Matiaske W, Spieß M, Berlemann M, Borg I, Altobelli CF, Hinz H, Jirjahn U. Case study research: approaches, methods, contribution to theory. 1st ed. Mering: Rainer Hampp Verlag; 2016.

RIVM - Rijksinstituut voor Volksgezondheid en Milieu. Home | Samen meten aan luchtkwaliteit. 2018. https:/www. samenmetenaanluchtkwaliteit.nl/. Accessed 31 Oct 2018.

Roorda C, Wittmayer J, Henneman P, van Steenbergen F, Frantzeskaki N, Loorbach D. Transition management in the urban context: guidance manual. 2014. https://drift.eur.nl/publications/transition-management-urban-context-guidance-manual/.

RWTH Aachen University. Profile - RWTH AACHEN UNIVERSITY - English. 2018. https://www.rwth-aachen.de/cms/root/DieRWTH/ emp/Profil/lidx/1/. Accessed 31 Oct 2018.

Severijnen M. PM-LAB - Towards a particulate matter information system for the Euregion Meuse-Rhine: Technical report 2013; 2014. https://doi.org/10.13140/RG.2.2.36443.00808.

Thunis P, Degraeuwe B, Pisoni E, Ferrari F, Clappier A. On the design and assessment of regional air quality plans: the SHERPA approach. J Environ Manag. 2016a;183:952-8. https://doi.org/10.1016/j.jenvman.2016.09.049.

Thunis P, Miranda A, Baldasano JM, Blond N, Douros J, Graff A, Janssen S, Juda-Rezler K, Karvosenoja N, Maffeis G, Martilli A, Rasoloharimahefa M, Real E, Viaene P, Volta M, White L. Ovenview of current regional and local scale air quality modelling practices: assessment and planning tools in the EU. Environ Sci Pol. 2016b;65:13-21. https://doi.org/10.1016/j.envsci.2016.03.013.

Truffer B, Murphy JT, Raven R. The geography of sustainability transitions: contours of an emerging theme. In: Truffer B, Murphy JT, Raven R, editors. Special section: the geography of sustainability transitions, vol 17; 2015. p. 63-72.

Turnheim B, Berkhout F, Geels F, Hof A, McMeekin A, Nykvist B, van Vuuren D. Evaluating sustainability transitions pathways: bridging analytical approaches to address governance challenges. Glob Environ Chang. 2015;35:239-53. https://doi.org/ 10.1016/.gloenvcha.2015.08.010.

UBA - Umweltbundesamt. Realemissionsmessungen an Kraftfahrzeugen. 2018. https://www.umweltbundesamt.de/themen/ verkehr-laerm/emissionsstandards/realemissionsmessungen-an-kraftfahrzeugen\#textpart-2. Accessed 7 July 2019.

WBGU - Wissenschaftlicher Beirat der Bundesregierung Globale Umweltveränderungen (WBGU). Humanity on the move: Unlocking the transformative power of cities: Flagship report. Berlin: WBGU - Wissenschaftlicher Beirat der Bundesregierung Globale Umweltveränderungen (WBGU); 2016.

WHO - World Health Organization. Ambient air pollution: a global assessment of exposure and burden of disease. 2016. http://www.who.int/phe/publications/air-pollution-global-assessment/en/. Accessed 5 Sept 2018.

WHO - World Health Organization. Ambient (outdoor) air quality and health. 2018. https://www.who.int/en/news-room/factsheets/detail/ambient-(outdoor)-air-quality-and-health. Accessed 24 Sept 2019.

Wittmayer JM, Loorbach D. Governing transitions in cities: fostering alternative ideas, practices, and social relations through transition management. In: Loorbach D, Wittmayer JM, Shiroyama H, Fujino J, Mizuguchi S, editors. Governance of urban sustainability transitions: European and Asian experiences, 1st ed. Tokyo, s.l.: Springer Japan; 2016. p. 13-32.

Wolfram M. Urban planning and transition management: rationalities, instruments and dialectics. In: Frantzeskaki N, Hölscher K, Bach M, Avelino F, editors. Co-creating sustainable urban futures: a primer on applying transition management in cities. Cham: Springer International Publishing; 2018. p. 103-25.

\section{Publisher's Note}

Springer Nature remains neutral with regard to jurisdictional claims in published maps and institutional affiliations. 